\title{
REVITALISASI PERAN LEMBAGA PERADILAN DI INDONESIA
}

\author{
Asep Saepullah \\ Fakultas Syari'ah dan Ekonomi Islam \\ Institut Agama Islam Negeri Syekh Nurjati Cirebon \\ J1. Perjuangan By Pass Sunyaragi Cirebon \\ email: $\underline{\text { Saepullah@gmail.com }}$
}

\begin{abstract}
Abstrak
Terciptanya kehidupan yang kondusif, nyaman, dan tentram dalam berbangsa dan bernegara merupan suatu momentum yang dinanti-nantikan oleh sebagian besar penghunyi republik ini. Adapun untuk mewujudkan cita-cita tersebut adalah dengan cara mensterilisasi serta memperbaiki beberapa hal yang memiliki pengaruh signifikan terhadap kehidupan masyarakat di Negara ini, salah satunya adalah masalah penegakan hukum. Penegakan hukum pada hakikatnya merupakan interaksi antara berbagai perilaku manusia yang mewakili kepentingan-kepentingan yang berbeda dalam bingkai aturan yang telah disepakati bersama. Oleh karena itu, penegakan hukum tidak dapat semata-mata dianggap sebagai proses menerapkan hukum sebagaimana pendapat kaum legalistik. Namun proses penegakan hukum mempunyai dimensi yang lebih luas daripada pendapat tersebut, karena dalam penegakan hukum akan melibatkan dimensi perilaku manusia.
\end{abstract}

Keywords : Revitalisasi, Peradilan Agama

\begin{abstract}
The creation of a conducive, comfortable, and peaceful life in the nation and state is a moment that most of the republic's sounding is waiting for. As for the realization of these ideals is to sterilize and improve some things that have a significant influence on the lives of people in this country, one of which is the problem of law enforcement. Law enforcement is essentially an interaction between various human behaviors that represent different interests within the framework of mutually agreed rules. Therefore, law enforcement can not merely be regarded as a process of applying the law as the legalists argue. But the law enforcement process has a broader dimension than that opinion, because in law enforcement will involve a dimension of human behavior.
\end{abstract}

Keywords : Revitalization, Religious Courts 


\section{A. Pendahuluan}

Lembaga peradilan sebagai tempat untuk mencari keadilan bagi setiap warga negara merupakan badan yang berdiri sendiri (independen) dan otonom,salah satu unsur penting dalam lembaga peradilan adalah Hakim.Hal ini dikarenakan seorang hakim mempunyai peran yang besar dalam memberikan keadilan kepada setiap orang yang berperkara di persidangan. Sehingga diharapkan seorang hakim di dalam memeriksa, menyelesaikan, dan memutus suatu perkara juga harus bebas dari pengaruh apa atau siapapun untuk memberikan putusan yang seadil-adilnya kepada setiap orang yang berperkara di pengadilan.

Oleh karena itu hakim sebagai penegak hukum harus benar-benar meguasai hukum dalam hal ini hukum acara perdata. Sesuai dengan system yang dianut Indonesia bahwa dalam suatu sidang itu harus dipimpin oleh seorang hakim, dan hakim harus aktif bertanya, maksud dari hal tersebut adalah untuk menemukan kebenaran.

Dalam sengketa yang diajukan dimuka persidangan tersebut para pihak yang bersengketa mengajukan dalil-dalil yang saling bertentangan. Hakim harus memeriksa dan menetapkan dalil-dalil manakah yang benar dan dalildalil manakah yang tidak benar. Dalam melakukan pemeriksaan ini, hakim harus mengindahkan aturan-aturan tentang pembuktian yang merupakan hukum pembuktian.

Pada hakekatnya yang harus dibuktikan adalah peristiwanya dan bukan hukumnya. Oleh karena itu yang wajib membuktikan peristiwanya atau mengajukan alat bukti adalah para pihak, sedangkan hakim harus menentukan hukumnya terhadap peristiwa yang telah terbukti tersebut. Jadi hakim di dalam proses perkara perdata harus menetapkan dan menemukan kebenaran peristiwa atau hubungan hukumnya terhadap peristiwa yang telah ditetapkan itu. ${ }^{1}$

Proses reformasi peradilan telah berjalan selama sepuluh tahun dengan berbagai keberhasilan antara lain perbaikan sistem informasi, penyatuan atap, peningkatan gaji dan remunerasi dan seterusnya namun hingga persoalan utama peradilan tetap tidak terpecahkan. Akar permasalahan yang melingkupi Mahkamah Agung adalah tingginya tumpukan perkara yang berdampak pada menurunnya kualitas dan inkonsistensi putusan. Rendahnya kepercayaan masyarakat terhadap pengadilan sebagai lembaga penyelesaian sengketa dapat dilihat ditandai dengan rendahnya jumlah perkara yang masuk pada pengadilan tingkat pertama. Untuk itu reformasi peradilan harus ditujukan pada upaya mengembalikan fungsi MA sebagai pengadilan tertinggi dalam menjaga kesatuan hukum, dan revitalisasi fungsi pengadilan untuk menyediakan pengadilan yang terjangkau bagi masyarakat.

Dalam rangka meningkatkan akses masyarakat pada pengadilan maka perlu dibentuk Pengadilan Acara Cepat atau small claim court yang memiliki proses sederhana dan memiliki kemudahan akses secara fisik,

\footnotetext{
${ }^{1}$ Sudikno mertokusumo. Hukum acara perdata Indonesia, (Yogyakarta: Liberti, 2002), hlm. 106
} 
biaya rendah, informalitas proses dan kapasitas untuk mengelola hubungan antara pihak yang bersengketa. Upaya lain yang ditawarkan untuk meningkatkan akses keadilan adalah melalui desentralisasi pengelolaan sumber daya manusia khususnya hakim dimana rekrutmen hakim dilaksanakan di tingkat regional dan sistem mutasi terbatas secara regional. ${ }^{2}$

B. Peran Lembaga Peradilan Dalam Menciptakan Keadilan Masyarakat

Peradilan dalam istilah inggris disebut judiciary dan rechspraak dalam bahasa Belanda maksudnya adalah segala sesuatu yang berhubungan dengan tugas Negara dalam menegakan hukum dan keadilan. Menurut R.Subekti dan R. Tjitrosoedibio, pengertian peradilan adalah segala sesuatu yang berhubungan dengan tugas Negara untuk menegakkan hukum dan keadilan. Penggunaan istilah Peradilan (rechtspraak/judiciary) menunjuk kepada proses untuk memberikan keadilan dalam rangka menegakan hukum (het rechtspreken), sedangkan pengadilan ditujukan kepada badan atau wadah yang memberikan peradilan. Jadi pengadilan bukanlah merupakan satu satunya wadah yang menyelenggarakan peradilan. Pengertian peradilan menurut Sjachran Basah, adalah segala sesuatu yang berkaitan dengan tugas dalam memutus perkara dengan menerapkan hukum, menemukan hukum in concreto dalam mempertahankan dan menjamin ditaatinya hukum materil,

\footnotetext{
2 Norman Arief, Konsep Ideal Peradilan Indonesia: Menciptakan Kesatuan Hukum \& Meningkatkan Akses Masyarakat pada Keadilan, (Jakarta: Lembaga Kajian dan Advokasi untuk Independensi Peradilan (LeIP), 2010), hlm. v
}

dengan menggunakan cara procedural yang ditetapkan oleh hukum formal. ${ }^{3}$

Dalam kamus Bahasa Indonesia, peradilan adalah segala sesuatu mengenai perkara peradilan. ${ }^{4}$ Peradilan juga dapat diartikan suatu proses pemberian keadilan disuatu lembaga. ${ }^{5}$ Dalam kamus Bahasa Arab disebut dengan istilah qadha yang berarti menetapkan, memutuskan, menyelesaikan, mendamaikan. Qadha menurut istilah adalah penyelesaian sengketa antara dua orang yang bersengketa, yang mana penyelesaiannya diselesaikan menurut ketetapan-ketetapan (hukum) dari Allah dan Rasul. Sedangkan pengadilan adalah badan atau organisasi yang diadakan oleh negara untuk mengurus atau mengadili perselisihan-perselisihan hukum. ${ }^{6}$

Masalah utama penegakan hukum di negara-negara berkembang khususnya Indonesia bukanlah pada sistem hukum itu sendiri, melainkan pada kualitas manusia yang menjalankan hukum (penegak hukum). Dengan demikian peranan manusia yang menjalankan hukum itu (penegak hukum) menempati posisi strategis. Masalah transparansi penegak hukum berkaitan erat dengan akuntabilitas kinerja lembaga penegak hukum. Undang-undang No. 28 tahun 1999 tentang penyelenggara negara yang bersih dan bebas dari korupsi, kolusi

3 Sjachran Basah, Mengenal Peradilan di Indonesia, (Jakarta: Raja Grafindo Persada, 1995), hlm. 9

4 Cik Hasan Basri, Peradilan Agama di Indonesia, (Jakarta: PT Raja Grafindo Persada, 2003), hlm. 2.

5 MohammadDaud Ali, Pengantar Ilmu Hukum dan tata Hukum Islam di Indonesia, (Jakarta: PT Raja Grafindo Persada 2005), hlm. 278

${ }^{6}$ Cik Hasan Basri, op.cit, hlm. 3 
dan nepotisme, telah menetapkan beberapa asas. Asas-asas tersebut mempunyai tujuan, yaitu sebagai pedoman bagi para penyelenggara negara untuk dapat mewujudkan penyelenggara yang mampu menjalankan fungsi dan tugasnya secara sungguh-sungguh dan penuh tanggung jawab. $^{7}$

Penegak hukum merupakan golongan panutan dalam masyarakat, yang hendaknya mempunyai kemampuankemampuan tertentu, sesuai dengan aspirasi masyarakat. Mereka harus dapat berkomunikasi dan mendapatkan pengertian dari golongan sasaran (masyarakat), di samping mampu membawakan atau menjalankan peranan yang dapat diterima oleh mereka. Selain itu, maka golongan panutan harus dapat memanfaatkan unsurunsur pola tradisional tertentu, sehingga menggairahkan partispasi dari golongan sasaran atau masyarakat luas. Golongan panutan juga harus dapat memilih waktu dan lingkungan yang tepat di dalam memperkenalkan norma-norma atau kaidahkaidah hukum yang baru serta memberikan keteladanan yang baik.

Namun sebagaimana yang telah kita ketahui bahwa salah satu penyebab lemahnya penegakan hukum di Indonesia adalah masih rendahnya moralitas aparat penegak hukum (hakim, polisi, jaksa dan advokat ) serta judicial corruption yang

7 Siswanto Sunarso. Penegakan Hukum Psikotropika, Kajian Sosiologi Hukum. (Jakarta: PT RajaGrafindo Persada, 2005), hlm. 50

8 Soerjono Soekanto, Faktor-Faktor yang Mempengaruhi Penegakan Hukum. (Jakarta: PT. Raja Grafindo Persada 2011), hlm. 34 sudah terlanjur mendarah daging sehingga sampai saat ini sulit sekali diberantas. Adanya judicial corruption jelas menyulitkan penegakan hukum di Indonesia karena para penegak hukum yang seharusnya menegakkan hukum terlibat dalam praktek korupsi, sehingga sulit diharapkan bisa ikut menciptakan pemerintahan yang baik atau good governance. Penegakan hukum hanya bisa dilakukan apabila lembaga-lembaga hukum (hakim, jaksa, polis dan advokat) bertindak profesional, jujur dan menerapkan prinsipprinsip good governance.

Beberapa permasalahan mengenai penegakan hukum, tentunya tidak dapat terlepas dari kenyataan, bahwa berfungsinya hukum sangatlah tergantung pada hubungan yang serasi antara hukum itu sendiri, penegak hukum, fasilitasnya dan masyarakat yang diaturnya. Kepincangan pada salah satu unsur, tidak menutup kemungkinan akan mengakibatkan bahwa seluruh sistem akan terkena pengaruh negatifnya. ${ }^{9}$ Misalnya, kalau hukum tertulis yang mengatur suatu bidang kehidupan tertentu dan bidang-bidang lainnya yang berkaitan berada dalam kepincangan. Maka seluruh lapisan masyarakat akan merasakan akibat pahitnya.

Satjipto Rahardjo berpendapat, untuk menyebarkan fora pendistribusi keadilan tidak semestinya terkonsentrasi hanya pada satu lembaga yang bernama

${ }^{9}$ Soerjono Soekanto dan Mustafa Abdullah. Sosiologi Hukum dalam Masyarakat. (Jakarta: Rajawali Press, 1987), hlm. 20 
pengadilan. $^{10} \quad$ Keberadaan lembaga peradilan sebagai salah satu pendistribusi keadilan tidak dapat dilepaskan dari penerimaan dan penggunaan hukum modern di Indonesia. Hukum modern di Indonesia diterima dan dijalankan sebagai suatu institusi baru yang didatangkan atau dipaksakan (imposed) dari luar. Padahal secara jujur, dilihat dari optik sosio kultural, ${ }^{11}$ hukum modern yang kita pakai tetap merupakan semacam "benda asing dalam tubuh kita." Oleh sebab itu, untuk menanggulangi kesulitan yang dialami bangsa Indonesia disebabkan menggunakan hukum modern, adalah menjadikan hukum modern sebagai kaidah positif menjadi kaidah cultural. Persoalannya, karena sistem hukum modern yang liberal itu tidak dirancang untuk memikirkan dan memberikan keadilan yang luas kepada masyarakat, melainkan untuk melindungi kemerdekaan individu. Di samping itu juga, akibat sistem hukum liberal tidak dirancang untuk memberikan keadilan substantif, maka seorang dengan kelebihan materil akan memperoleh "keadilan" yang lebih daripada yang tidak. ${ }^{12}$

Apabila kita terus menerus berpegang kepada doktrin liberal, maka kita akan tetap berputar-putar dalam pusaran

\footnotetext{
${ }^{10}$ Satjipto Rahardjo, “Membangun Keadilan Alternatif”; Kompas, Rabu, 5 April 1995

${ }^{11}$ Eman Suparman, Persepsi tentang Keadilan dan Budaya Hukum dalam Penyelesaian Sengketa, Makalah, TT. hlm. 4

${ }^{12}$ Satjipto Rahardjo, "Rekonstruksi Pemikiran Hukum di Era Reformasi”; dalam Makalah Seminar Nasional 'Menggugat Pemikiran Hukum Positivistik di Era Reformasi', PDIH-Undip Angkatan V, Semarang, Sabtu, 22 Juli 2000, hlm.8
}

kesulitan untuk mendatangkan atau menciptakan keadilan dalam masyarakat. Dalam rangka melepaskan diri dari doktrin liberal itulah, maka gagasan orang-orang atau pihak-pihak untuk mencari dan menemukan keadilan melalui forum alternatif di luar lembaga pengadilan modern sesungguhnya merupakan upaya penolakan terhadap cara berpikir hukum yang tertutup. Hal itu disebabkan para pencari keadilan masih sangat merasakan, betapa pun tidak sekuat seperti pada abad ke-sembilan belas, filsafat liberal dalam hukum dewasa ini masih sangat besar memberi saham terhadap kesulitan menegakkan keadilan substansial (substantial justice). ${ }^{13}$

Sehubungan dengan hal tersebut di atas, maka Pengadilan di sini bukan diartikan semata-mata sebagai badan untuk mengadili, melainkan sebagai pengertian yang abstrak, yaitu "hal memberikan keadilan". Hal memberikan keadilan berarti yang bertalian dengan tugas badan pengadilan atau hakim dalam memberi keadilan, yaitu memberikan kepada yang bersangkutan. Konkritnya kepada yang mohon keadilan apa yang menjadi haknya atau apa hukumnya. ${ }^{14}$ Eksistensi pengadilan sebagai lembaga yang berfungsi menyelenggarakan proses peradilan dalam menerima, memeriksa, dan mengadili sengketa masyarakat, tugas-tuganya diwakili oleh hakim. Oleh karena itu, kepercayaan masyarakat terhadap hukum serta institusi peradilan di negara ini ditentukan oleh

\footnotetext{
${ }^{13}$ Eman Suparman, Op.Cit., hlm. 5 Sudikno Mertokusumo, Sejarah Peradilan...Op. Cit., hlm. 2.
} 
kredibilitas dan profesionalitas hakim dalam menjalankan tugasnya menyelesaikan sengketa serta menegakkan keadilan.

Jadi, para hakim dituntut untuk secara totalitas melibatkan dirinya pada saat membuat putusan, bukan hanya mengandalkan kemahirannya mengenai perundang-undangan. Menurut Roeslan Saleh, ${ }^{15}$ seorang hakim diharapkan senantiasa menempatkan dirinya dalam hukum, sehingga hukum baginya merupakan hakekat dari hidupnya. Hakim tidak boleh menganggap hukum sebagai suatu rangkaian dari larangan dan perintah yang akan mengurangi kemerdekaannya, melainkan sebaliknya hukum harus menjadi sesuatu yang mengisi kemerdekaannya. Oleh karena "hukum itu bukan semata-mata peraturan atau undang-undang, tetapi lebih daripada itu: 'perilaku.' Undang-undang memang penting dalam negara hukum, akan tetapi bukan segalanya dan proses memberi keadilan kepada masyarakat tidak begitu saja berakhir melalui kelahiran pasal-pasal undang-undang."

Seperti telah diutarakan di muka, bahwa dalam sistem hukum di manapun di dunia, keadilan selalu menjadi objek perburuan melalui lembaga pengadilannya. Namun demikian kerusakan dan kemerosotan dalam perburuan keadilan melalui hukum modern disebabkan permainan prosedur yang menyebabkan timbul pertanyaan "apakah

\footnotetext{
15 Roeslan Saleh, Mengadili Sebagai Pergulatan Kemanusiaan, (Jakarta: Aksara Baru, 1979), hlm. 29.
}

pengadilan itu tempat mencari keadilan atau kemenangan?"16

Keadilan memang barang yang abstrak dan karena itu perburuan terhadap keadilan merupakan usaha yang berat dan melelahkan. Sementara itu, pengadilan sebagai institusi pendistribusi keadilan telah menjadi institusi modern yang dirancang secara spesifik bersamaan dengan munculnya negara modern sekitar abad ke delapan belas. Oleh sebab itu, pekerjaan mengadili tidak lagi hanya bersifat mengadili secara substansial seperti pada masa lampau ketika Khadi Justice, yaitu suatu peradilan yang tidak berorientasi kepada "fixed rules of formally rational law," melainkan kepada hukum substantif yang bertolak dari postulat-postulat etika, religi, politik, dan lain-lain pertimbangan kemanfaatan. Setelah menjadi institusi

16 Satjipto Rahardjo, "Indonesia Butuh Keadilan yang Progresif;" Kompas., Sabtu, 12 Oktober 2002

17.Menurut Weber, sebelum hadir negara modern, rasionalisasi belum masuk ke dalam pengadilan, sehingga tidak ada perpecahan antara formal justice dengan substantial justice. Sementara itu pengadilan modern mempunyai arsitektur yang demikian formal rasional sebagai bagian dari karakteristik hukum modern yang disebut tipe legal domination. Oleh karena itu, pengadilan muncul sebagai hasil rancangan artifisial yang rasional seperti yang kita kenal sekarang, sehingga berbicara tentang keadilan, dikenal terdapat dua macam, yaitu (i) keadilan substansial (substantial justice) dan (ii) keadilan formal (formal justice atau legal justice). Sedangkan pada masa lampau, pembedaan keadilan seperti itu tidak ada, oleh karena tidak ada peraturan yang kompleks yang mengatur bagaimana putusan pengadilan diberikan. Pada waktu itu mengadili adalah memberikan putusan secara substansial." Lihat, Satjipto Rahardjo, Sosiologi Hukum: Perkembangan, Metode, dan Pilihan Masalah, (Surakarta: Muhammadiyah University Press, 2004), hlm. $134-136$. 
modern, pengadilan merupakan penerapan dari prosedur yang ketat. ${ }^{17}$

Berdasarkan optik sosiologi hukum yang lebih memperhatikan fungsi dari badan yang menjalankan fungsi mengadili, maka dalam rangka menemukan keadilan serta dimana keadilan diputuskan, faktor lembaga atau badan pemutus keadilan yang diakui menjadi tidak penting. Putusan tentang keadilan dapat dilakukan dimana saja dalam masyarakat, tidak perlu harus di pengadilan. Oleh karenanya, menegakkan dan menemukan keadilan tidak semata-mata harus dilakukan melalui struktur formal lembaga pengadilan. Fungsi mengadili dapat dilakukan dan berlangsung di banyak lokasi, sehingga Marc Galanter ${ }^{18}$ mengungkapkan dengan sebutan "justice in many rooms." Atas dasar hal itu, maka memilih forum arbitrase atau mediasi untuk menyelesaikan sengketa-sengketa bisnis merupakan kecenderungan beralihnya minat masyarakat pencari keadilan dari menggunakan jalur litigasi pada pengadilan kepada jalur lain yang formatnya lebih tidak terstruktur secara formal.

Namun demikian, bentuk yang disebut terakhir itu diyakini oleh para penggunanya akan mampu melahirkan keadilan substansial. Padahal selama beberapa dekade masyarakat di sejumlah negara, termasuk di Indonesia memberikan kepercayaan kepada lembaga pengadilan untuk mengelola sengketa yang sedang dihadapi, dengan harapan akan memperoleh

\footnotetext{
${ }^{18}$ Marc Galanter, "Justice in Many Rooms"; dalam Maurio Cappelletti (ed), Access to Justice and The Welfare State, (Italy: European University Institute, 1981), hlm. 147-182.
}

keadilan sebagaimana secara normatif dan eksplisit disebutkan dalam ketentuan perundang-undangan. ${ }^{19}$ Akan tetapi faktanya lembaga pengadilan telah terbukti tidak mampu memenuhi harapan masyarakat pencari keadilan. Banyak faktor memang yang menyebabkan pengadilan dalam perjalanan sejarahnya menjadi seperti itu.

Lemahnya mentalitas aparat penegak hukum mengakibatkan penegakkan hukum tidak berjalan sebagaimana mestinya. Banyak faktor yang mempengaruhi lemahnya mentalitas aparat penegak hukum diantaranya lemahnya pemahaman agama, ekonomi, proses rekruitmen yang tidak transparan dan lain sebagainya. Sehingga dapat dipertegas bahwa faktor penegak hukum memainkan peran penting dalam memfungsikan hukum. Kalau peraturan sudah baik, tetapi kualitas penegak hukum rendah maka akan ada masalah. Demikian juga, apabila peraturannya buruk sedangkan kualitas penegak hukum baik, kemungkinan munculnya masalah masih terbuka.

Kondisi riil yang terjadi saat ini di Indonesia mengindikasikan adanya kegagalan aparat-aparat penegak hukum dalam menegakan hukum. Kegagalan penegakan hukum secara keseluruhan dapat dilihat dari kondisi ketidakmampuan (unability) dan ketidakmauan (unwillingness) dari aparat penegak hukum itu sendiri. Ketidakmampuan penegakan hukum diakibatkan profesionalisme aparat yang kurang, sedangkan ketidakmauan

19 Psl.3 Ayat (2) UU No.14/1970 tentang Ketentuan-Ketentuan Pokok Kekuasaan Kehakiman. 
penegakan hukum berkait masalah KKN (korupsi kolusi dan nepotisme) yang dilakukan oleh aparat hukum sudah menjadi rahasia umum. Terlepas dari dua hal di atas lemahnya penegakan hukum di Indonesia juga dapat kita lihat dari ketidakpuasan masyarakat karena hukum yang nota benenya sebagai wadah untuk mencari keadilan bagi masyarakat, tetapi malah memberikan rasa ketidakadilan.

\section{B. Peran Peradilan Dalam Kesejahteraan Masyarakat}

Jika kita amati potret penegakan hukum di Indonesia saat ini belumlah berjalan dengan baik, bahkan bisa dikatakan buruk. Lemahnya penegakan hukum di Indonesia saat ini dapat tercermin dari berbagai penyelesaian kasus besar yang belum tuntas salah satunya praktek korupsi yang menggurita, namun ironisnya para pelakunya sangat sedikit yang terjerat oleh hukum. ${ }^{20}$ Kenyataan tersebut justru berbanding terbalik dengan beberapa kasus yang melibatkan rakyat kecil, dalam hal ini aparat penegakkan hukum cepat tanggap, karena sebagaimana kita ketahui yang terlibat kasus korupsi merupakan kalangan berdasi alias para pejabat dan orang-orang berduit yang memiliki kekuatan (power) untuk menginterfensi efektifitas dari penegakan hukum itu sendiri.

Realita penegakan hukum yang demikian sudah pasti akan menciderai hati

20 Lihat, Mahmud Kusuma, Menyelami Semangat Hukum Progresif Terapi Paradigmatik Bagi Lemahnya Hukum Indonesia, (Yogyakarta: antonyLip, 2009), hlm. 66 rakyat kecil yang akan berujung pada ketidakpercayaan masyarakat pada hukum, khususnya aparat penegak hukum itu sendiri. $^{21} \quad$ Sebagaimana sama-sama kita ketahui para pencari keadilan yang note bene adalah masyarakat kecil sering dibuat frustasi oleh para penegak hukum yang nyatanya lebih memihak pada golongan berduit. Sehingga orang sering menggambarkan kalau hukum Indonesia seperti jaring laba-laba yang hanya mampu menangkap hewan-hewan kecil, namun tidak mampu menahan hewan besar tetapi hewan besar tersebutlah yang mungkin menghancurkan seluruh jaring laba-laba. ${ }^{22}$

Problematika penegakan hukum yang mengandung unsur ketidakadilan tersebut mengakibatkan adanya isu mafia peradilan, keadilan dapat dibeli, munculnya bahasa-bahasa yang sarkastis dengan plesetan HAKIM (Hubungi Aku Kalau Ingin Menang), KUHAP diplesetkan sebagai Kurang Uang Hukuman Penjara, tidaklah muncul begitu saja. Kesemuanya ini

21 Negara Indonesia adalah negara hukum, begitu yang dinyatakan dalam konstitusi kita UUD Negara RI 1945 pasal 1 ayat (3) yang dirumuskan dalam amandemennya yang ketiga, Agustus 2001 silam. Sehingga seharusnya seluruh sendi kehidupan dalam bermasyarakat dan bernegara kita harus berdasarkan pada norma-norma hukum. Artinya hukum harus dijadikan panglima dalam penyelesaian masalah-masalah yang berkenaan dengan individu, masyarakat dan Negara. Tetapi sampai saat ini dalam kenyataannya masyarakat seperti tidak percaya kepada hukum sebagai satu-satunya solusi atas permasalahan yang terjadi di sekitarnya. Mungkin hal ini disebabkan karena sudah sangat kronisnya krisis kepercayaan masyarakat terhadap hukum, istilah ini tidak lazim dipakai dalam bahasa Indonesia dimana penyumbang terbesar krisis tersebut adalah dari para penegak hukumnya sendiri.(Abdul Ghofur Anshori, Op.Cit., hlm. 155-156)

${ }^{22}$ Ibid., hlm. 156 
merupakan "produk sampingan" dari bekerjanya lembaga-lembaga hukum itu sendiri. Ungkap-ungkapan ini merupakan reaksi dari rasa keadilan masyarakat yang terkoyak karena bekerja lembaga-lembaga hukum yang tidak profesional maupun putusan hakim/putusan pengadilan yang semata-mata hanya berlandaskan pada aspek yuridis. Berlakunya hukum di tengah-tengah masyarakat, mengemban tujuan untuk mewujudkan keadilan, kepastian hukum dan kemanfaatan dan pemberdayaan sosial bagi masyarakatnya.

Untuk menuju pada cita-cita pengadilan sebagai pengayoman masyarakat, maka pengadilan harus senantiasa mengedapankan tiga tujuan hukum di atas dalam setiap putusan yang dibuatnya. Hal ini sejalan dengan apa yang menjadi dasar berpijaknya hukum yaitu "hukum untuk kesejahteraan masyarakat". Dengan demikian, pada akhirnya tidak hanya dikatakan sebagai Law and Order (Hukum dan Ketertiban) tetapi telah berubah menjadi Law, Order dan Justice (Hukum, Ketertiban, dan Ketentraman). Adanya dimensi keadilan dan ketentraman yang merupakan manifestasi bekerjanya lembaga pengadilan, akan semakin mendekatkan citacita pengadilan sebagai pengayom masyarakat. $^{23}$

Penyelesaian sengketa melalui pengadilan merupakan wujud kepercayaan masyarakat terhadap tegaknya hukum di Indonesia. Kepercayaan masyarakat terhadap hukum akan bergeser manakala hukum tersebut tidak dapat memberikan

${ }^{23}$ Zudan Arif Fakrulloh, Op.Cit., hlm. 26 jaminan keadilan dan menimbulkan kerugian baik materi maupun non materi. Berbelit-belitnya proses peradilan menyebabkan para pihak yang terlibat menghendaki penyelesaian secara cepat dengan berbagai cara. Adapun cara yang ditempuh tersebut terkadang bertentangan dengan aturan hukum yang berlaku dan aparat penegak hukum sendiri membuka peluang terhadap cara yang dilakukan para pihak. Sehingga dampak yang lebih luas adalah budaya hukum yang terbentuk dimasyarakat tidak selaras dengan tujuan dan cita-cita hukum. Hukum dijadikan bisnis bagi para pihak yang terlibat beserta aparat penegak hukum yang didalamnya terdapat tawar-menawar perkara.

Sebagai contoh kecil rusaknya budaya hukum dimasyarakat yakni penyelesaian terhadap pelanggaran lalu lintas yang dilakukan melalui proses damai antara aparat penegak hukum dengan masyarakat yang melanggar. Proses damai tersebut berisi tawar-menawar harga sebuah pelanggaran. Selain itu juga usaha masyarakat untuk menghidar bila sudah berhadapan dengan permasalahan hukum. Hal tersebut lebih disebabkan karena masyarakat tidak percaya terhadap proses hukum di Indonesia.

Baik substansi hukum, struktur hukum maupun budaya hukum saling keterkaitan antara satu dengan yang lain dan tidak dapat dipisahkan. Dalam pelaksanaannya diantara ketiganya harus tercipta hubungan yang saling mendukung agar tercipta pola hidup aman, tertib, tentram dan damai. Begitu juga dalam penegakan hukum ketiga unsur ini 
memegang peranan yang signifikan untuk menciptakan penegakan hukum yang yang berorientasi pada keadilan sebagaiman yang dicita-citakan oleh sebagian besar para pencari kebenaran via pengadilan atau melalui lembaga penegakan hukum lainnya.

Beranjak dari fenomena-fenomena yang terjadi khususnya dalam penegakan hukum, maka dapat diasumsikan bahwa penegakan hukum di Indonesia saat ini belum berjalan secara efektif dan efisien. Hal ini karena beberapa unsur yang telah disebutkan di atas belum menampakkan keselarasan dalam mewujudkan tujuan yang paling mendasar dari penegakan hukum yaitu untuk menciptakan keadilan yang dicita-citakan masyarakat. Kenyataan ini dapat dibuktikan dengan banyaknya kasus besar seperti korupsi yang menjamur menggerogoti negeri ini, namun para pelakunya sedikit sekali yang dijatuhi hukuman dan sanksi yang tegas.

Bahkan yang lebih mencengangkan dan membuat ngilu hati masyarakat ketika kasus besar tersebut dibandingkan dengan kasus yang menimpa rakyat kecil yang begitu cepat diselesaikan dengan penjatuhan hukuman, terkadang hukumannya pun jauh dari rasa keadilan. Akibatnya sudah pasti banyak menimbulkan protes dan gejolak di tengah-tengah masyarakat. Fenomena semacam ini apabila terus berlanjut tentu akan mengakibatkan tingkat kepercayaan masyarakat kepada hukum semakin luntur bahkan bisa hilang. Untuk membendung kemungkinan tersebut, maka penegakan hukum harus dilakukan dengan menjunjung tinggi rasa keadilan, bukan hanya keadilan berdasarkan undang-undang (yuridis) semata tetapi juga dengan rasa keadilan yang dicita-citakan masyarakat.

\section{Kesimpulan}

Antara hukum dan keadilan merupakan dua sisi mata uang yang tidak bisa dipisahkan, hal ini karena hanya melalui suatu tata hukum yang adil orang dapat hidup dengan damai menuju suatu kesejahteraan jasmani maupun rohani. Untuk menegakkan dan menemukan keadilan tidak semata-mata harus dilakukan melalui struktur formal lembaga pengadilan. Fungsi mengadili dapat dilakukan dan berlangsung di banyak lokasi (justice in many rooms) seperti melalui forum arbitrase atau mediasi juga bias mencari keadilan. Proses penegakan hukum di Indonesia belum relevan dengan keadilan yang dicita-citakan oleh masyarakat. Hal ini karena penegakan hukum itu sendiri masih tebang-pilih. Sehingga orang sering menggambarkan kalau hukum Indonesia seperti jaring laba-laba yang hanya mampu menangkap hewan-hewan kecil, namun tidak mampu menahan hewan besar tetapi hewan besar tersebutlah yang mungkin menghancurkan seluruh jaring laba-laba.

\section{DAFTAR PUSTAKA}

Arief, Norman, Konsep Ideal Peradilan Indonesia: Menciptakan Kesatuan Hukum \& Meningkatkan Akses Masyarakat pada Keadilan, Jakarta: Lembaga Kajian dan Advokasi untuk Independensi Peradilan (LeIP), 2010

Basah, Sjachran, Mengenal Peradilan di Indonesia, Jakarta: Raja Grafindo Persada, 1995 
Cik Hasan Basri, Peradilan Agama di Indonesia, Jakarta: PT Raja Grafindo Persada, 2003

Daud Ali, Mohammad, Pengantar Ilmu Hukum dan tata Hukum Islam di Indonesia, Jakarta: PT Raja Grafindo Persada 2005

Galanter, Marc "Justice in Many Rooms"; dalam Maurio Cappelletti (ed), Access to Justice and The Welfare State, Italy: European University Institute, 1981

Mahmud Kusuma, Menyelami Semangat Hukum Progresif Terapi Paradigmatik Bagi Lemahnya Hukum Indonesia, Yogyakarta: antonyLip, 2009

Mertokusumo. Sudikno, Hukum acara perdata Indonesia, Yogyakarta: Liberti, 2002

Rahardjo, Satjipto, "Indonesia Butuh Keadilan yang Progresif;" Kompas. Sabtu, 12 Oktober 2002

Rahardjo, Satjipto, "Membangun Keadilan Alternatif'; Kompas, Rabu, 5 April 1995.

Rahardjo, Satjipto, "Rekonstruksi Pemikiran Hukum di Era Reformasi"; dalam Makalah Seminar Nasional 'Menggugat Pemikiran Hukum Positivistik di Era Reformasi', PDIH-Undip Angkatan V, Semarang, Sabtu, 22 Juli 2000

Rahardjo, Satjipto, Sosiologi Hukum: Perkembangan, Metode, dan Pilihan Masalah, Surakarta:
Muhammadiyah University Press, 2004

Saleh, Roeslan, Mengadili Sebagai Pergulatan Kemanusiaan, Jakarta: Aksara Baru, 1979

Soekanto, Soerjono, Faktor-Faktor yang Mempengaruhi Penegakan Hukum. Jakarta: PT. Raja Grafindo Persada 2011

Soerjono Soekanto dan Mustafa Abdullah. Sosiologi Hukum dalam Masyarakat. Jakarta: Rajawali Press, 1987

Sunarso. Siswanto, Penegakan Hukum Psikotropika, Kajian Sosiologi Hukum. Jakarta: VPT RajaGrafindo Persada, 2005

Suparman, Eman, Persepsi tentang Keadilan dan Budaya Hukum dalam Penyelesaian Sengketa, Makalah, TT 